\title{
Ethical Imperatives of CEOs: Creating the Virtuous Corporation
}

\author{
Hershey H. Friedman, Linda W. Friedman, Frimette Kass-Shraibman \\ City University of New York, United States
}

\begin{abstract}
Companies that are going to thrive must have a soul. Those that are only concerned with "maximising shareholder wealth" or "maximising profit" will find themselves going the way Enron went. CEOs will have to lead the revolution and should be the ones exhorting executives to make spiritual values or virtue, not just profit, the core values of a firm. A true measure of corporate performance is multidimensional and has to include the short-term, the long-term, risk, environmental issues, society, employees, customers, suppliers, and government. This paper shows how a firm can acquire a soul and even be profitable doing it.
\end{abstract}

\section{Keywords}

Corporate performance, chief executive officers, spiritual values

\section{Introduction}

The following quote, attributed to Abraham Lincoln (Gore, 2007: 88), describes what many people may be feeling after the latest financial meltdown, which started with the subprime real estate debacle.

I see in the near future a crisis approaching that unnerves me and causes me to tremble for the safety of my country. . . corporations have been enthroned, and an era of corruption in high places will follow, and the money power of the country will endeavour to prolong its reign by working upon the prejudices of the people until all wealth is aggregated in a few hands and the Republic is destroyed.

Copyright (C) 2008 Victoria University. This document has been published as part of the Journal of Business Systems, Governance and Ethics in both online and print formats. Educational and non-profit institutions are granted a nonexclusive licence to utilise this document in whole or in part for personal or classroom use without fee, provided that correct attribution and citation are made and this copyright statement is reproduced. Any other usage is prohibited without the express permission of the
The cost of the subprime mess will most likely be measured in trillions of dollars; millions of Americans are in danger of losing their homes (Morris, 2008). This crisis has spread to many other countries. Morris (2008) asserts that the "subprime is just the first big boulder in an avalanche of asset writedowns." Of course, those who helped create the disaster will undoubtedly 
remain super wealthy. This is the latest crisis but there were a number of previous financial disasters that occurred (e.g., Enron, Worldcom, Adelphia, etc. fiascos; Savings and Loan scandal; dot-com debacle) not that long ago and continue to occur. Trillions of dollars of investors' funds and pensions have disappeared, as well as numerous jobs, because of unscrupulous CEOs, corporate officers, accountants, investment bankers, regulators, politicians, financial analysts, auditors, and attorneys (Mills, 2003).

CEOs are seen as part of the problem, not the solution. The scandals involving backdating of options has made it obvious that CEOs and top management of many firms are more concerned about enriching themselves than in maximising shareholder wealth. Backdating of options is not an aberration; there is evidence that $29 \%$ of public corporations have engaged in this practice (Burrows, 2007). A large number of companies are using compensation consultants to justify high salaries for CEOs. There seems to be no question that firms that use compensation consultants do pay considerably more to their CEOs; what is unclear is whether this is the result of a conflict of interest or other factors (Knowledge@Wharton, 2008). We may be seeing the beginning of another huge scandal: CEOs colluding with private equity firms to sell the companies they head at bargain basement prices. To accomplish this, they would likely need the assistance of investment bankers willing to bend the rules (Smith, 2007).

It is not surprising that Americans have lost their faith in the business world and the people who run it. In a recent Roper poll, only $2 \%$ of respondents felt that Fortune 500 CEOs were "very trustworthy" (Deutsch, 2005); the overwhelming majority of Americans (72\%) believe that "wrongdoing" is widespread in the business world. Robert S. Miller, CEO of Delphi, asserts: "Society has come to believe that the term 'crooked CEO' is redundant" (Deutsch, 2005).

According to a recent Pew Research Center (2008) survey, only 41\% of Americans feel that they are better off now than they were five years ago - this is the worst percentage in 44 years of taking polls. There is clearly a widespread feeling of pessimism among Americans about their economic situation. This is not surprising given that the average American is seeing wealth aggregating in the hands of the few while the average worker is lucky if his/her job is not outsourced to a foreign country.

Greider (2003) observes that because greed is the foundation of capitalism, it has caused capitalism to become dysfunctional. The corporation has lost its soul and destroys the environment in the name of profit. Moreover, there is virtually no democracy in the corporate world and executives act like lords of the manor with employees as their serfs. Bebchuk and Fried $(2004: 1 ; 2005)$ note that the ratio of CEO pay at large firms relative to the pay of the average worker has grown to 500:1. Samuelson (2006) found that from 1995 to 2005, median CEO compensation increased 151\% ( $\$ 2.7$ million to $\$ 6.8$ million); median salary increases for all full-time employees increased only $32 \%$. In addition, the ratio of median CEO salary/median worker salary rose from 94 to 179 in the same time period. It is becoming quite apparent that executive compensation is not tied to company performance.

It is becoming clear now that Wall Street's inept compensation system - one which encouraged bankers and traders to take enormous risks with money belonging to stockholders - was partially responsible for the current financial debacle (Cohan, 2008). Cohan (2008) observes: "the inevitable consequences of encouraging smart people to take risks, free of accountability, with other people's money are easy to fathom." It is not surprising that CEOs have lost their credibility in the United States. What is ironic is that a significant number of CEOs who led their firms to insolvency or close to it have done quite well. One example is Richard Fuld, CEO of Lehman Brothers. Between 1993 and 2007, he earned approximately half-a-billion dollars; Lehman Brothers no longer exists. E. Stanley O'Neal, former CEO of Merrill Lynch, left with \$161 million (Kristof, 2008). The big losers in the current financial mess have not been the CEOs; rather, the employees, shareholders, and taxpayer have incurred the real suffering.

Jeb Bush, governor of Florida, contends that "...if the rewards for CEOs and their teams become extraordinarily high with no link to performance — and shareholders are left holding the bag - then it undermines people's confidence in capitalism itself'(Kirkland, 2006). 
Bogle (2005: 5) claims that capitalism needs a soul if it is to thrive.

...capitalism requires a structure and a value system that people believe in and can depend on. We do not need a Pollyannaish faith in the goodwill of mankind, but we do need the confidence that promises and commitments, once made, will be kept. We also need assurances that the system as a whole does not unduly benefit some at the expense of others.

Wilson (1997) declares that "capitalism has won the economic battle around the world, but it is everywhere on the defensive with respect to the moral struggle for men's souls... The lasting challenge to capitalism is moral." Kolp and Rea (2006: 25) are of the opinion that the belief that the primary job of a CEO is to maximise shareholder wealth (or the wealth of the CEO) leads to corporations losing their souls, a good example of which is Enron. Kevin Rollins, CEO of Dell, refers to "the soul of Dell" and understands that a company can only have a soul if it is ethical (Kolp and Rea, 2006: 25).

Gore and Blood (2008) assert that market capitalism is now at a critical juncture. A major transformation must take place if capitalism will thrive. They believe that the following are some of the key causes of the current financial meltdown: "short-termism (including but not limited to increased leverage), poor governance and regulation, misaligned compensation and incentive systems, lack of transparency, and in some firms, poor leadership and a dysfunctional business culture."

The corporation is a place where all that seems to matter is self-interest. Executives have not been part of the solution and, indeed, have contributed greatly to the problem. This paper is a call to action for the corporate world. CEOs must see their role as more than maximising earnings per share and/or maximising shareholder wealth. They have the responsibility to ensure that firms behave in an ethical and spiritual way; they also have to do what is right for all stakeholders, including employees, customers, suppliers, government, and the environment.

Many of the above quotations use the term "soul." There is no question that this is a vague term and may have some religious connotations. Regardless, there is a reason that this term is used. It suggests a type of capitalism that is not solely concerned with self interest. Many other terms used to describe this new kind of capitalism include phrases such as "moral capitalism," "karma capitalism," "spiritual capitalism," "triple bottom line," "sustainable capitalism," "socially responsible capitalism," etc.

Lawrence Summers, President-Elect Obama's chief economic adviser, said:

For it is the irony of the market system that while its very success depends on harnessing the power of self-interest, its very sustainability depends upon people's willingness to engage in acts that are not self-interested. What you have seen at Enron, at the New York Stock Exchange, and in too many other places suggests that there have been failures in inculcating the right values. (Summers, 2003)

\section{Spiritual Values and Virtue}

The number of CEOs interested in spiritual values continues to increase. What at first appeared to be a fad is becoming a revolution. Kerns (2002) notes that there are a huge number of books and websites dealing with business that discuss spirituality; a large number of business "gurus" are giving seminars on the subject. Rhodes (2006) points out that workplace spirituality has finally become a respectable subject, one that is discussed in management textbooks and has special interest groups dedicated to it. A number of major magazines have had issues dealing with religion and/or spirituality in the workplace (e.g., Fortune, 2001; Business Week, 1999; and The New York Times Magazine, 2004). Indeed, 90\% of Americans describe themselves as spiritual vs. $75 \%$ who believe that they are religious (Iannaccone, 2003). One study showed that $70 \%$ of college students believe that religion is important to their lives; another study found that $77 \%$ of college students prayed (Connor, 2006). White (2006) cites a study conducted by UCLA's Higher Education Research Institute that shows that spirituality is very important to college students today. In fact, $80 \%$ of students are interested in spirituality; $76 \%$ are searching for meaning and purpose in life; and $79 \%$ believe in God. Like it or not, White believes that 
academe will have no choice but to be "visionary about the emerging issue of students' need for spiritual development and must empower them to articulate it in the academy..."

Spirituality should not be confused with religion, although the two are related: one can be spiritual and yet not be part of any religious group. White (2006) describes the distinction as follows: "spirituality is the view that an individual's constructed personal belief in a higher power or Supreme Being is not necessarily linked to any religious institution, orientation, or particular dogma." Spiritual people want their lives and jobs to have purpose and meaning. Spiritual, as well as religious, people, are concerned with making a difference, and desire to make the world a better place. Those who are not spiritual believe in maximising their own pleasure and minimising their pain; i.e., all that matters is money, fame, and/or power. The "greed is good" philosophy espoused by Gordon Gekko in the movie Wall Street is certainly not consistent with a spiritual firm. Mangham (2006) notes that a number of scholars maintain that "today's business schools, by elevating shareholder profit above social benefits and other concerns, may have unintentionally become breeding grounds for a generation of Gordon Gekkos." John J. Fernandes, president of the Association to Advance Collegiate Schools of Business (AACSB), also believes that schools of business have overemphasised the importance of profit maximisation (Mangan, 2006).

Nowadays, people do not wish to leave their core values "outside the office door" (Porth, 1997). It is quite common to find Bible and prayer groups that meet on a regular basis at many companies in the United States; one estimate is that there are 10,000 of them (Business Week, 1999). Fogel (2000), a 1993 Nobel laureate, is one economist who stresses the importance of spirituality in the new economy. He identifies fifteen vital spiritual resources that include concepts such as "a sense of purpose, a sense of opportunity, a sense of community, a strong family ethic, a strong work ethic, and high self esteem." Clearly, spiritual values are important to many people.

\section{Can Spiritual Values Provide a Competitive Edge for a Firm?}

There are those who feel that virtue and corporate social responsibility must stem from a business imperative; the belief of "doing well by doing good" is part of this approach. Others feel that corporate social responsibility must stem from an ethical imperative. Thus, "doing good" should be important to a firm even when profits are falling (Tragakis, 2008). It may not make that much of a difference how an organisation feels since the evidence is mounting that firms that are truly committed to being socially responsible are more successful than those that are not.

Pava (2003: 62-63) states that "virtually no empirical study has ever documented a financial cost associated with increased corporate social responsibility activities." A firm with spiritual values may actually have a competitive edge over firms that do not. Studies of numerous industries show that virtuous organisations, i.e., those that possess institutionalised compassion, forgiveness, and integrity, "enjoy higher levels of productivity, quality, profitability, customer satisfaction, and employee engagement" (Brady 2006; Paine, 2003:53). Vogel (2005: 45) disagrees and claims that there is little evidence that there is a positive relationship between being socially responsible and profitability. But even Vogel agrees that "this does not mean there is no business case for virtue. It is rather to suggest that any such claim must be more nuanced."

The benefits of being virtuous and socially responsible do not always manifest themselves immediately; it may take years for them to appear. After all, some of the benefits of being virtuous are long-term and relate to attracting and retaining motivated employees, developing a reputation for providing superior products and stellar service, and increased market capitalisation. This does not happen immediately and profits may not increase for a while. Hollender and Fenichell (2004: 44-45) feel that the reputation of a company ("goodwill") and its brands ("brand equity") are more valuable than the firm's buildings and machines. They are a firm's most valuable asset and determine market capitalisation. The second most valuable asset is the "human capital of the employees." Thus, firms that harm their reputations will seriously damage their market capitalisations. Acting in a socially responsible manner, on the other hand, increases the market capitalisation of a firm. Hollender and Fenichell (2004: 26-27) assert that 
there is strong positive correlation between being a value-driven firm and financial performance. Firms that make virtue part of their culture have done much better in terms of long-term financial performance than those only concerned with profit maximisation.

Kiley (2006) discusses the BusinessWeek/Interbrand "Best Global Brands" of 2006. The world's most valuable brands are Coca-Cola, Microsoft, IBM, and GE. One brand that was losing value for several years was McDonald's. Adverse publicity regarding the nutritional value of its products and obesity associated with eating fast foods caused the market capitalisation of McDonald's to decline by $\$ 12.2$ billion in the five years ending in 2003. Studies showed that mothers did not trust the nutritional value of eating at McDonald's (Kiley, 2006). The company recognised that it had to appeal to mothers and offer healthier foods. The strategy seems to be working: McDonald's global brand value has increased this year by $6 \%$ (Kiley, 2006). Hyundai is another company whose reputation for quality was so poor that it almost left the United States market in 1998. The company took quality much more seriously after that and even offered a 100,000 mile/10-year warranty. Hyundai's global brand value has increased by $17 \%$ this year. Clearly, the market places a high value on brand and company names that represent quality and concern about the consumer. It goes without saying that virtuous firms would not consider selling shoddy products and providing inferior service. Pride in what one does is the mantra of a spiritual organisation.

Batstone (2003, p. 3) makes the point that employees working for ethical firms are six times more likely to remain in their companies as compared to those employed at unethical firms. Can spiritual values be employed in the workplace and make an organisation more profitable and improve employee satisfaction? The answer is a resounding yes! Mitroff and Denton (1999) provide strong empirical evidence that firms with spiritual values will perform better than those without. Those firms have employees that are more loyal, productive, and innovative than other companies.

Tragakis (2008) claims that there are at least a dozen ways (higher sales, less risk, enhanced corporate reputation and brand image, better employee relations and higher productivity, enhanced relationship with investors, etc.) that a commitment to corporate social responsibility can help a firm improve its financial performance and profits. He feels that these arguments have helped silence those that claim that "going beyond basic obligations and legal compliance is folly." There is evidence that consumers will pay a premium for products sold by firms that are socially responsible and will purchase products made by firms that are not socially responsible only if they are sold at a huge discount (Trudel and Cotte, 2008).

By no means is it clear that being socially responsible will hurt a company's bottom line; on the contrary, there is considerable evidence that it will benefit a firm in many different ways. Of course, the benefits may not be realised immediately. The current financial meltdown demonstrates that in many cases there may ultimately be a huge price to pay for acting in a socially irresponsible or unethical manner. As Friedman (2008) observes, referring to the current financial meltdown: "That's how we got here - a near total breakdown of responsibility at every link in our financial chain, and now we either bail out the people who brought us here or risk a total systemic crash. These are the wages of our sins."

\section{Exemplars: Firms with Spiritual Values}

The following are some companies which have made spiritual values an integral part of their business plans. These companies are successful and demonstrate the principle of "doing well by doing good."

Milliman et al. (1999), in a case study approach, demonstrate how Southwest Airlines uses a "spiritual values-based model" to make its firm successful. A spiritual company, according to the authors, addresses the question of making a positive contribution to the world. Bailey (2006) found that many Southwest Airline employees are now millionaires (employees have a profit-sharing plan, not a pension), yet continue to work. They have a great deal of pride in the company and in what they accomplished. Southwest Airlines has prospered while many airlines such as Pan Am and Eastern have 
disappeared. Southwest has the lowest costs in the airline industry but pays the highest wages. It is able to do this by having the most productive employees in the airline industry.

Ben \& Jerry's ice cream company is another firm that stresses spiritual values. Ben Cohen, cofounder of the company, says: "At Ben and Jerry's, we learned that there's a spiritual life to businesses as there is in the lives of individuals." He also asserts: "As you give, you receive. As you help others, you are helped in return. For people, for businesses, for nations - it's all the same... We're all interconnected, and as we help others, we cannot help but help ourselves" (Saylor, 2005). Ben Cohen and Jerry Greenfield developed a two-part bottom line for their company: each month, they want to see how many people they have helped. They also make a point to help their own community by purchasing from local dairy farms in Vermont (Saylor, 2005).

In 2004, Paulette Cole, President and CEO of ABC Carpet and Home, decided to transform her firm into one that sold products that helped society, i.e., had "social resonance" (Owens, 2006). Thus, shoppers could buy jewellery made by African women with AIDS and/or ceramics that would help support foster schools in Guatemala. Owens (2006) cites a study conducted by two researchers at the $\mathrm{ABC}$ Carpet and Home store which found that its customers (they tend to be affluent and interested in social causes) were willing to pay 10 to $20 \%$ more for products with labels that indicate they were manufactured at places using fair labour practices. Patricia Karte, CEO of Dancing Deer Baking, is another executive who is concerned more about health, ecology, philanthropy, and caring for employees than profits (Perman, 2006). Employees receive stock options and free lunches. Thirty-five percent of proceeds from one line of cakes go to help the homeless find jobs and housing.

John P. Mackey, CEO and co-founder of Whole Foods Market, asserts that customer satisfaction is more important than profit maximisation. He is an advocate for what is referred to as values-driven capitalism. The firm has to consciously work to improve society and not rely solely on the "invisible hand" of the marketplace to achieve this result. In fact, the company stopped selling lobsters because it did not like the way the animals were treated. The company is also increasing its spending on its purchases of produce from local farmers (Nocera, 2006).

Jim Sinegal, co-founder and CEO of Costco, feels that Costco has a simple code of ethics, which has contributed to its success. It includes the following: "obeying the law, taking care of members, taking care of employees and respecting suppliers" (Grimley, 2008). According to Sinegal, "running a good business and having a good sense of ethics is a standard if you want to be successful."

Tom Chappell (1999), CEO of Tom's of Maine, describes how his firm has thrived by managing "upside down." This means allowing values as well as profit to drive the company. In fact, Chappel believes that "social and moral responsibilities" have to be the core of the business. He defines values as what people consider "important in life" and what we want to "pass on to our children and our communities." Chappell's approach is for people who believe there is more to life than just making a great deal of money. It also respects customers, employees, the environment, and the community. Chappell shows how anyone can follow his approach by using what he calls the "Seven Intentions of Values-Centered Leadership." One of these values deals with connecting with others (Chappell, 1999: 180-183).

Tom's of Maine also has a Statement of Beliefs that can be used by any firm that is interested in spiritual values (Chappell, 1993: 32):

- We believe that both human beings and nature have inherent worth and deserve our respect.

- We believe in products that are safe, effective, and made of natural ingredients.

- We believe that our company and our products are unique and worthwhile, and that we can sustain these genuine qualities with an ongoing commitment to innovation and creativity.

- We believe that we have a responsibility to cultivate the best relationships possible with our coworkers, customers, owners, agents, suppliers, and our community.

- We believe in providing employees with a safe and fulfilling work environment, and an opportunity to grow and learn. 
- We believe that our company can be financially successful while behaving in a socially responsible and environmentally sensitive manner.

Sant and Bakke founded AES, a power company, with the understanding that they would be socially responsible as well as profitable (Paine, 2003: 182-197). In fact, they "embedded" honesty, concern for the environment, empowerment, diversity, and values into the essence of the company. The company's website (http://www.aes.com/aes/index?page=our values) notes that the following values are "a key component of the AES culture":

Put Safety First - We will always put safety first - for our people, contractors and communities.

Act With Integrity - We are honest, trustworthy and dependable. Integrity is at the core of all we do - how we conduct ourselves and how we interact with one another and all of our stakeholders.

Honour Commitments - We honour our commitments to our customers, teammates, communities, owners, suppliers and partners, and we want our businesses, on the whole, to make a positive contribution to society.

Strive For Excellence - We strive to be the best in all that we do and to perform at worldclass levels.

Have Fun Through Work - We work because work can be fun, fulfilling and exciting. We enjoy our work and appreciate the fun of being part of a team that is making a difference. And when it stops being that way, we will change what or how we do things.

Novartis received the 2006 DNWE (German Business Ethics Network) Prize for Corporate Ethics. What makes this even more special is that this is the first time a foreign company was awarded this German prize. At the Novartis Foundation website (http://www.novartisfoundation.com len/articles/business/business corporate ethics.htm, there is an interesting paper by Leisinger (1994) dealing with corporate ethics. This paper discusses the following principles of "moral common sense" discussed by Goodpaster (1984: 6): "Avoid harming others; Respect the rights of others; Do not lie or cheat; Keep promises and contracts; Obey the law; Prevent harm to others; Help those in need; Be fair; Reinforce these imperatives in others." The above principles are certainly consistent with spiritual values. It is no wonder that a firm concerned with the above core values won an ethics award.

Wal-Mart Watch (www.WalmartWatch.com) is of the opinion that Wal-Mart has strayed from the values of its founder, Sam Walton. Indeed, Wal-Mart is under attack for not having good values. The firm has been accused of abusing employees by underpaying them, overworking them, and not providing adequate health insurance. Wal-MartWatch.com has run advertisements which they call "A Handshake with Sam" urging Wal-Mart to abide by the philosophy of its founder, Sam Walton:

I am absolutely convinced that the only way we can improve one another's quality of life, which is something very real to those of us who grew up in the Depression, is through what we call free enterprise - practiced correctly and morally.

CEOs should see their role as ensuring that a firm is honest and has spiritual values. A firm with spiritual values is not a firm that forces its beliefs on others. Most people do not wish to work in a firm where employees spend much of their time proselytising. Firms that look down at individuals of other faiths and see them as needing spiritual redemption do not have spiritual values. A key component of spiritual values is showing respect for other people and their religious values.

\section{Mission Statements Should Include Spiritual Values}

In looking at the above exemplars, it seems that a good place to start would be to examine the corporate mission statement. A firm that is interested in developing spiritual values must first thoroughly scrutinise its mission statement. Mission statements should not only be concerned with profit and 
growth; maximising shareholder wealth is not what it is all about. A mission statement should say something about a firm's moral and ethical values. The needs of customers, suppliers, society, employees, government, and the environment should be addressed in the statement. Snider, Hill, and Martin (2003) did find that the websites of many of the top 50 US and top 50 non-American multinational firms make statements regarding core values of the firm and indicating a commitment to stakeholders including customers, employees, stockholders, and society. In addition, there is a mention of the importance of the caring for the environment.

Major business leaders who attended the World Economic Forum were asked for their primary measure of success. Only $20 \%$ mentioned profitability. The majority mentioned the reputation of the corporation, integrity, and high quality products (Hindery, 2005: 10). A good mission statement will mention ideas such as producing high-quality products; the importance of integrity in business; providing employees with meaningful and fulfilling work that provides dignity and the opportunity to grow; respect and concern for the environment; cultivating positive relationships with suppliers and customers; helping the local community; and concern for society. Of course, profits are necessary or the company will not survive. However, firms that do not care about customer satisfaction and virtue will also find it difficult to survive.

Wal-Mart Watch (2005) lists seven principles that it believes define an organisation's obligations to the common good. All are derived from ideas expressed by Sam Walton in his book Made in America.

- Protect human dignity based on: "If you want people in the stores to take care of the customers, you have to make sure you are taking care of the people in the stores."

- Ensure quality and affordable health care coverage based on: "You can't create a team spirit when the situation is so one-sided, when management gets so much and workers get so little of the pie."

- Use market power to improve supplier conditions and wages based on: "We still want to drive a hard bargain, but now we need to guard against abusing our power."

- Enable and embrace self sufficiency based on: "Maybe the most important way in which we at Wal-Mart believe in giving something back is through our commitment to using the power of this enormous enterprise as a force for change."

- Buy local first based on: "For Wal-Mart to maintain its position in the hearts of our customers, we have to study more ways we can give something back to our communities."

- Keep it clean based on: "I'd like to believe that as Wal-Mart continues to thrive and grow, it can come to live up to what someone once called us: the Lighthouse of the Ozarks."

- Prove worthy of the public trust based on: "As long as we're managing our company well, as long as we take care of our people and our customers, keep our eyes on those fundamentals, we are going to be successful. Of course, it takes an observing, discerning person to judge those fundamentals for himself."

\section{Conclusion}

For a company to thrive, it must have a soul. CEOs will have to lead the revolution and should be the ones exhorting executives to make spiritual values, not just profit, the core values of a firm. Corgel, Geron, and Riley (2004) make the point that CEOs have to take the lead in ensuring that financial statements are believable. There is evidence that CEOs can provide the vision and serve as transformational leaders that encourage their organisations to become moral and socially responsible (Waldman, Siegel, and Javidan, 2006). It is becoming more and more apparent that companies that are only concerned with "maximising shareholder wealth" or "maximising profit" will find themselves going the way Enron went. Even powerful firms too big to fail are being forced into takeovers or begging for 
government handouts to survive (e.g., Citigroup, AIG, Merrill Lynch, etc.). It is foolish to believe that corporate performance can be measured by using only one criterion such as maximising shareholder wealth or maximising profit (Pava, 2003: 8). A true measure of corporate performance is multidimensional and has to include the short-term, the long-term, risk, the environment, society, employees, customers, suppliers, and government. Maximising profit one year by sacrificing the future of the company, antagonising employees so they will attempt to seek employment elsewhere at the first opportunity, creating toxic dumps that will result in numerous future lawsuits, or selling substandard products that will fall apart after a few years of use are not ways to build a strong, viable company. The role of the CEO is not to make earnings look good in the short-run so that a few executives can make a killing before abandoning a sinking ship. CEOs have obligations to all stakeholders; their job is to ensure that a company is run in a way that it is healthy and will survive and prosper.

Lundegaard (2006) discusses the phrase used in the Superman show (first radio, then television), "truth, justice, and the American way." We have become so cynical about this that when Superman, in a 1978 film, says to Lois Lane that he is here to fight for the above, she makes the point that "you're going to end up fighting every elected official in the country." We would add that he would have to fight almost every CEO in the world if things do not change. It does not take a Superman to fight for these values; every CEO, American and foreign, can and should fight for truth, justice, compassion, human dignity, a meaningful life, and freedom.

CEOs have the obligation to lead the charge and transform companies into those with spiritual values. What makes life consequential is helping people, providing productive and meaningful jobs, not increasing the pay of top management. The corporation also has a responsibility to help humankind achieve its ultimate goal of creating a just and caring society.

\section{References}

Bailey, Jeff (2006, May 15). On some flights, millionaires serve the drinks. New York Times, A1, A16. Batstone, David (2003). Saving the corporate soul. San Francisco, CA: Jossey-Bass.

Bebchuk, Lucian and Fried, J. (2004). Pay without performance: The unfulfilled promise of executive compensation. Cambridge, MA: Harvard University Press.

Bebchuk, Lucian and Grinstein, Y. (2005). The growth of executive pay. Oxford Review of Economic Policy, 21(2), 283-303.

Bogle, John C. (2005). The battle for the soul of capitalism. New Haven, CT: Yale University Press.

Brady, Diane (2006, June 26). Charm offensive: Why America's CEOs are suddenly so eager to be loved. Business Week, 76-80.

Burrows, Peter (2007, January 15). He's making hay as CEOs squirm. Business Week, 64-65.

Business Week (1999, November 1). Religion in the workplace, 150-158

Chappell, Tom (1999). Managing upside down. New York: William Morrow and Company.

Chappell, Tom (1993). The soul of a business: Managing for profit and the common good. New York: Bantam.

Cohan, William D. (2008, November 16). Our risk, Wall Street's reward. New York Times, Week in Review, 13.

Connor, W. Robert (2006, June 9). The right time and place for big questions. Chronicle Review, B8 B9.

Corgel, Richard, Geron, J. and Riley, J. (2004). CEO leadership in improving corporate governance: The significance of CEO support to the effectiveness of the audit committee. Handbook of Business Strategy, 5(1), 45-50.

Deutsch, Claudia H. (2005, December 9). Take your best shot: New surveys show that big business has a P.R. problem. New York Times, C1.

Fogel, Robert W. (2000). The fourth great awakening. Chicago: University of Chicago Press.

Fortune (2001, July 9). God and Business.

Friedman, Thomas L. (2008, November 26). All fall down. A33. 
Goodpaster Kenneth E .(1984). Ethics in Management. Harvard Business School, Boston: Harvard Business School Publishing.

Gore, Al and Blood, D. (2008, November 5). We need sustainable capitalism. Wall Street Journal. Retrieved November 29, 2009 from http://online.wsi.com/article/SB122584367114799137.html

Gore, $\mathrm{Al}$ (2007). The Assault on Reason. New York: Penguin Group.

Greider, William (2003). The soul of capitalism: Opening a path to a moral economy. New York: Simon and Schuster.

Grimley, Brynn (2008, March 20). Costco CEO: Ethics 'Imperative.' Kitsap Sun, Retrieved April 25, 2008 from http://www.kitsapsun.com/news/2008/Mar/20/costco-ceo-attests-to-ethics-importance/

Hindery, Leo (2005). It takes a CEO: It's time to lead with integrity. New York: Free Press.

Hollender, Jeffrey and Fenichell, S. (2004). What matters most. New York: Basic Books.

Kerns, Charles D. (2002). Putting spirituality to work. Graziadio Business Report. Retrieved June 19 from http://gbr.pepperdine.edu/021/faith.html

Kiley, David (2006, August 7). Best global brands. Business Week, 54-66.

Kirkland, Rik (2006, June 30). The real CEO pay problem. Fortune. Retrieved September 17, 2006 from http://money.cnn.com/magazines/fortune/fortune archive/2006/07/10/8380799/index.htm

Knowledge@Wharton (2008, April 16). Conpensation consultants and conflicts of interest: Two different views. Retrieved April 18, 2008 from http://knowledge. wharton.upenn.edu/article.cfm?articleid=1941

Kolp, Alan and Rea, P. (2006). Leading with integrity: Character-based leadership. Cincinnati, OH: Atomic Dog Publishing.

Kristof, Nicholas D. (2008, September 18). Need a job? $\$ 17,000$ an hour. No success required. New York Times. A35.

Leisinger, Klaus M. (1994). Corporate ethics and international business: Some basic issues. Novartis Foundation for Sustainable Development. Retrieved May 30, 2006 from http://www.novartisfoundation.com/en/articles/business/business corporate ethics.htm

Lundegaard, Erik (2006, June 30). Truth, justice and (fill in the blank). New York Times, OP-ED, A23. Mangan, Katherine (2006, June 23). Agents of fortune. Chronicle of Higher Education, A14 -A16.

Milliman, John, Ferguson, J., Trickett, D. and Condemi, B. (1999). Spirit and community at Southwest Airlines. Journal of Organizational Change, 12(3), 221-233.

Mills, D. Quinn (2003). Wheel, deal and steal: Deceptive accounting, deceitful CEOs, and ineffective reforms. Upper Saddle River, NJ: FT Prentice Hall.

Mitroff, Ian I. And Denton, E. A. (1999). A spiritual audit of corporate America: A hard look at spirituality, religion, and values in the workplace. San Francisco: Jossey-Bass.

Morris, Charles R. (2008). The trillion dollar meltdown. New York: PublicAffairs.

New York Times Magazine (2004, October 31). With God at Our Desks.

Nocera, Joe (2006, July 15). A tussle of sorts, over organics. New York Times, C1, C8.

Owens, Mitchell (2006, May 25). Saving the world, a carpet at a time. New York Times, F1, F4.

Pava, Moses L. (2003). Leading with meaning: Using covenantal leadership to build a better organization. New York: Palgrave Macmillan.

Paine, Lynn S. (2003). Value shift. New York: McGraw-Hill.

Perman, Stacy (2006, August 21). Scones and social responsibility. Business Week, 38.

Pew Research Center (2008, April 9). Inside the middle class: Bad times hit the good life. Retrieved April 15, 2008 from http://pewresearch.org/pubs/793/inside-the-middle-class

Polonsky, Michael Jay, Rosenberger III, P. J. (2001). Paying the devil his due: Limits and liabilities of workplace spirituality," Business Horizons, September-October, 21- 30.

Porth, Stephen J. (1997). Spirit, religion and business ethics: A crossroads? Journal of Human Values, $3(1), 33-44$.

Rhodes, Kent (2006). Six components of a model for workplace spirituality. Graziadio Business Report, 9(2), Retrieved April 24, 2008 from http://gbr.pepperdine.edu/062/workplace.html.

Samuelson, Robert (2006, July 12). The CEO pay controversy. Real Clear Politics. Retrieved April 24, 2008 from http://www.realclearpolitics.com/articles/2006/07/the ceo pay controversy.html 
Saylor, Frederica (2005, May 12). Businesses benefit from a low-key spirituality. Science and Technology News. Retrieved May 3, 2006 from http://www.stnews.org/rlr-494.htm.

Smith, Yves (2007, February 7). Next type of CEO scandal. Naked Capitalism. Retrieved April 18, 2008 from http://www.nakedcapitalism.com/2007/02/next-type-of-ceo-scandal.html

Snider, Jamie, Hill, R.P., and Martin, D. (2003). Corporate social responsibility in the $21^{\text {st }}$ century: A view from the world's most successful firms. Journal of Business Ethics, 48, 175- 187.

Summers, Lawrence H. (2003, October 14). Remarks of Harvard University President Lawrence H. Summers at the Chicago Economic Club. Retrieved November 29, 2008 from http://www.president.harvard.edu/speeches/2003/chicago.html

Time (1999, November 1). Religion in the workplace, 150-158.

Tragakis, Chad (2008, March). Corporate responsibility: Going beyond the business case. The Voice of Corporate Citizenship. Boston College Center for Corporate Citizenship. Retrieved April 25, 2008 from http://www.bc.edu/centers/ccc/ce/newsletter/newsletter mar08.html

Trudel, Remi and Cotte, J. (2008, May 12). Does being ethical pay? Wall Street Journal, R1.

Vogel, David (2005). The Market for Virtue. Washington, D.C.: Brookings Institution Press.

Waldman, David A., Siegel, D. S., and Javidan, M. (2006). Components of CEO transformational leadership and corporate social responsibility. Journal of Management Studies, 43(8), 1703-1725.

Wal-Mart Watch (2005). The moral responsibilities of Wal-Mart. Retrieved April 24, 2008 from: http://walmartwatch.com/handshake

White, Stephen (2006). Spirituality and the intellectual development of college students: The new leadership challenge in higher education. International Electronic Journal for Leadership in Learning, 10(13), Retrieved April 24, 2008 from http://www.ucalgary.ca/ iejl1/volume10/white.htm

Wilson, James Q. (1997). The morality of capitalism. Fourteenth annual John Bonython lecture. Sydney, October 15. Retrieved April 24, 2008 from http://www.cis.org.au/events/jbl/ifr wilson.html 
